\title{
Erratum to: Journal of Indian Philosophy, Vol. 42, No. 2-3
}

\author{
Birgit Kellner • Sara McClintock
}

Published online: 22 April 2014

(C) Springer Science+Business Media Dordrecht 2014

\section{Erratum to: J Indian Philos DOI 10.1007/s10781-013-9190-7, DOI 10.1007/s10781-013-9200-9, DOI 10.1007/s10781-013-9201-8}

The Guest Editors Dr. Birgit Kellner and Dr. Sara McClintock of the Special Issue titled "ākāra in Buddhist Philosophical and Soteriological Analysis" would like to correct errors in the following articles.

In article 10.1007/s10781-013-9190-7 by Birgit Kellner, under the section, "Context 1: $\bar{A} k \bar{a} r a$ as Object-Form and the Denial of Perception as Activity" in paragraph 6 the noun phrase "tad vișayāntareșūtpadyanānam" is misspelt and the final sentence of the paragraph should read as "tad viṣayāntareșütpadyamānam tam tạ̣ viṣayam vijānātìty ucyate."

In paragraph 10 of the same section, the sentence "What, then, is its the object that caused resemblance?" should read as "What, then, is its resemblance?"

In the same article under the section "Appropriations of Abhidharmic Uses of $\bar{A} k \bar{a} r a$ in Buddhist Pramānavāda" in paragraph 1 the phrase "it usage in Abhidharmic contexts" is misspelt and the correct sentence should read as "The examination of contexts for $\bar{a} k \bar{a} r a$ in $\mathrm{AK}(\mathrm{Bh})$ consequently calls the view into

The online version of the original article can be found under doi:10.1007/s10781-013-9190-7, 10.1007/s10781-013-9200-9, 10.1007/s10781-013-9201-8.

B. Kellner $(\bowtie)$

Heidelberg Centre for Transcultural Studies, University of Heidelberg, Karl Jaspers Centre, Vossstrasse 2, Building 4400, 69115 Heidelberg, Germany

e-mail: kellner@asia-europe.uni-heidelberg.de

S. McClintock

Emory University, Atlanta, GA, USA

e-mail: slmmcli@emory.edu 
question that there is a general continuity between its usage as object-form in Buddhist pramāna discourse and its usage in Abhidharmic contexts."

In the same section in paragraph 2 the phrase "Concepts like as the contact" is misspelt and the correct sentence should read as "Concepts such as the contact between sense-faculty and object which is a part of the Nyāya definition of perception are not suited to explain this state of affairs."

In article 10.1007/s10781-013-9200-9 by Shinya Moriyama in footnote 22 the name "Kaamlaśîla" is misspelt and the sentence should read as "The same text is also quoted in Kamalaśîla's Madhyamakāloka."

In article 10.1007/s10781-013-9201-8 by Serena Saccone in footnote 26 line 3 the word "mürtānām" has been misspelt and the beginning of the sentence should read as "Cf. TSP ad 1967: niraṇśānām anekeșām aṇūnàm mūrtānām".

In the same article in footnote 70 line 3 the word "tadekāniyamājo" is misspelt and the correct sentence should read as "tad ekāniyamāj jñ̄anam uktam sāmānyagocaram ॥ (PV 3.195-196)". 